\title{
Spatially Explicit Model for Anaerobic Co-Digestion Facilities Location and Pre-Dimensioning Considering Spatial Distribution of Resource Supply and Biogas Yield in Northwest Portugal
}

\author{
Renata D'arc Coura ${ }^{1, *(\mathbb{D})}$, Joaquim Mamede Alonso ${ }^{2,3}$, Ana Cristina Rodrigues ${ }^{2,4} \mathbb{D D}$, Ana Isabel Ferraz ${ }^{2,4} \mathbb{D}$, \\ Nuno Mouta ${ }^{2}$, Renato Silva ${ }^{2}$ iD and A. G. Brito ${ }^{1}$ (D) \\ 1 LEAF-Linking Landscape, Environment, Agriculture and Food, Instituto Superior de Agronomia, \\ Universidade de Lisboa, Tapada da Ajuda, 1349-017 Lisboa, Portugal; agbrito@isa.ulisboa.pt \\ 2 ProMetheus-Research Unit in Materials, Energy and Environment for Sustainability, \\ Instituto Politécnico de Viana do Castelo, 4900-347 Viana do Castelo, Portugal; malonso@esa.ipvc.pt (J.M.A.); \\ acrodrigues@esa.ipvc.pt (A.C.R.); aferraz@esa.ipvc.pt (A.I.F.); nuno.mouta@esa.ipvc.pt (N.M.); \\ renato.silva@esa.ipvc.pt (R.S.) \\ 3 CIBIO.InBIO-Research Centre in Biodiversity and Genetic Resources, Campus de Vairão, \\ Universidade do Porto, Rua Padre Armando Quintas, 7 4485-661 Vairão, Portugal \\ 4 CEB-Centre of Biological Engineering, Campus de Gualtar, Universidade do Minho, \\ 4710-057 Braga, Portugal \\ * Correspondence: rcoura@esa.ipvc.pt or renatacoura@isa.ulisboa.pt
}

Citation: Coura, R.D.; Alonso, J.M.; Rodrigues, A.C.; Ferraz, A.I.; Mouta, N.; Silva, R.; Brito, A.G. Spatially Explicit Model for Anaerobic Co-Digestion

Facilities Location and

Pre-Dimensioning Considering Spatial Distribution of Resource Supply and Biogas Yield in Northwest Portugal. Appl. Sci. 2021, 11, 1841. https://doi.org/10.3390/ app11041841

Academic Editor: Gilberto Martins

Received: 31 December 2020

Accepted: 16 February 2021

Published: 19 February 2021

Publisher's Note: MDPI stays neutral with regard to jurisdictional claims in published maps and institutional affiliations.

Copyright: (C) 2021 by the authors Licensee MDPI, Basel, Switzerland. This article is an open access article distributed under the terms and conditions of the Creative Commons Attribution (CC BY) license (https:// creativecommons.org/licenses/by/ $4.0 /)$
Abstract: The high volumes of animal manure and sewage sludge, as a consequence of the development of intensive and specialized cattle dairy farms in peri-urban areas, pose challenges to local environmental quality and demands for systems innovation. Besides these negative impacts, energy recovery from biogas produced in anaerobic co-digestion processes should contribute to local sustainable development. This research considers technical data obtained from the optimization of biomethanization processes using sewage sludge and cattle manure liquid fraction, aiming to develop a spatially explicit model including multicriteria evaluation and an analytical hierarchy process to locate biogas production facilities, allocate energy resources and consider biogas unit pre-dimensioning analysis. According to the biophysical conditions and socioeconomic dynamics of the study area (Vila do Conde, Northwest Portugal), a spatially explicit model using multicriteria and multiobjective techniques allowed the definition of suitable locations, as well as the allocation of resources and support pre-dimensioning of biogas facilities. A p-median model allowed us to allocate resources and pre-dimensioning biogas facilities according to distance and accessibility elements. The results indicate: (i) the location of areas with adequate environmental conditions and socioeconomic suitability advantages to install biogas production facilities, and (ii) the ability to compare the options of centralized or distributed location alternatives and associated pre-dimensioning.

Keywords: spatial data; geographic information science; decision-support system; location-allocation; anaerobic co-digestion; analytic hierarchy process; biogas

\section{Introduction}

Economic competitive advantages found in (peri)urban areas promote population concentration, increasing rural-urban interfaces [1] and fostering changes in local consumption patterns and in waste and wastewater spatio-temporal production [2]. These processes contribute to sewage sludge (SwS) and animal manure production and accumulation [3] originating from local rural and urban activities, causing potential pressures and impacts on quality of life and natural resource management [4,5] of these complex socio-ecological systems [6]. However, these local or regional problems concerning the excess of organic loads can turn into opportunities resulting from bioenergy and nutrient recovery processes 
into fertilizers and energy, simultaneously promoting waste reduction and reuse and local circular (bio)economy innovation [4,5].

The prospect of resource scarcity has been a constant challenge, which reaffirms the necessity to develop new approaches and technologies, improve processes and innovate organizational systems. A holistic and transversal approach should incorporate the complex interdependence between water, energy and food resources (water-energy-food nexus) [7], integrating the complexity of local socio-ecological systems [8,9]. Public wastewater sanitation infrastructures, as major energy consumers within municipalities [10], need to adopt strategies that enhance the eco-efficiency of their facilities and that also seek to support other realities within the territory, such as waste and wastewater generating activities, that still lack proper treatment. In this context, dairy intensive farms, as large waste producers, still need the implementation of treatment technologies that promote the energetic valorization of this substrate typology. This reality demands for a local integrated management and spatio-environmental planning of peri-urban areas [1,11,12]. In that regard, the location, dimensioning and operation of some wastewater treatment plants (WWTPs) may be optimized with the integration of both waste and wastewater in order to meet the project dimensioning parameters.

In fact, as an endogenous source of energy, within the (bio)circular economy context, waste and wastewater from dairy farms could be incorporated by wastewater treatment facilities for anaerobic co-digestion and biogas production. However, the optimization of waste and wastewater management systems involves technological, organizational and territorial solutions regarding legal constraints (e.g., activity licensing), land use spatial planning [13,14], treatment and valorization facility design [15] and the optimization of the associated operational conditions [16].

Spatio-temporal patterns analysis of organic waste and wastewater production supports the identification, selection and management of treatment and valorization processes $[17,18]$. The territorial systems analysis also helps us to understand the structure and optimal operation of local treatment and energy recovery facilities [19-21]. The selection of adequate location and processes for sewage sludge and cattle manure treatment, reuse and valorization [22-24] is critical to ensure both processing facilities' viability and regional and local sustainability (including both in social, economic and environmental domains).

Territorial information systems development supported by geographic information systems (GIS) should support spatial, organizational and technological systems analysis, management and governance. Reference and thematic spatial databases [25], associated with different user profile management systems, can assist data analysis and simulation to define facilities' locations and support operation phases [26,27].

Ongoing research activities at a laboratorial and pilot scale aiming to develop scientific knowledge and improve these technological processes should also result in socioecological and spatial systems optimization. In this context, in a systemic approach to the energy efficiency of the territory, advanced studies have been carried out, aiming at the development of a spatially explicit model for anaerobic co-digestion facility location and pre-dimensioning, considering the spatial distribution of resource supply.

Increasing waste and wastewater production, European and national legal frameworks and strict requirements of service quality, associated with the advances and innovation of treatment processes regarding biogas production, are driver factors towards systems optimization supported in territorial and spatial knowledge [28].

Sustainable development demands innovative model governance and organizational solutions in suitable locations, associated with functional, social and economically viable processes and technological operations. Thus, data, information and knowledge from experimental assays [29] are integrated both in the definition of environmental, social and economic criteria at planning scale (location, allocation and pre-dimensioning existing and new potential biogas plants) and in biogas facility operation (organizational and logistic solutions) [30]. These potential advances consider the inclusive nature inherent to these processes, accounting for the responsibilities (legal, ethical, economic) and the 
opinions of the involved agents (researchers, farmers, politicians, technicians and all stakeholders) [31,32].

Biogas facility location requires multiple spatial criteria to obtain optimal, satisfactory or consensual solutions [33-35]. Therefore, planning phases consider the development of multi-criteria spatial decision models for facility location assessment. Environmental conditioning and planning constraints, aspects related to social sensitivities and options, as well as initial investment issues and operating costs are included in multiobjective models for the locating and pre-dimensioning of biogas facilities. Spatial data on: (i) environmental conditions (climate, geology, soil, orography, hydrology and species distribution); (ii) (socio)ecological systems, including population, demographic and economic data, including roads, transport, wastewater and energy infrastructures; and (iii) sewage sludge and animal manure production and associated spatio-temporal availability patterns are critical in the spatially explicit model development to support biogas plant location. Thus, data concerning waste production systems, treatment and valorization technologies and processes, such as biomethanization [24,36,37], should support facility location evaluation, as well as pre-dimensioning and operation [38-40], namely in biogas facilities planning [12,41].

\section{Materials and Methods}

The results from laboratorial scale experiments [29] and associated technical-scientific advances, as well as innovations in local circular (bio)economy models and practices, imply the development of spatial intelligence analysis models. The development of a spatially explicit model aims to assess the potential suitable locations for anaerobic co-digestion (ACoD) facilities (complementary/distributed or competitive/centralized biogas plants), allocate resources and consider biogas facility pre-dimensioning analysis. The present research includes the development of the following sequential methodological procedures.

\subsection{Scope, Objectives and Research Framework}

The present research aims to develop a spatially explicit model using an analytical hierarchy process (AHP) concerning the suitable location and the pre-dimensioning of biogas units in $\mathrm{ACoD}$ systems for sewage sludge and dairy cattle manure liquid fraction (CMLF) (urban and rural) treatment and valorization. The model development considers the test and local reality of Vila do Conde municipality (Northwest; NW Portugal) (Figure 1).
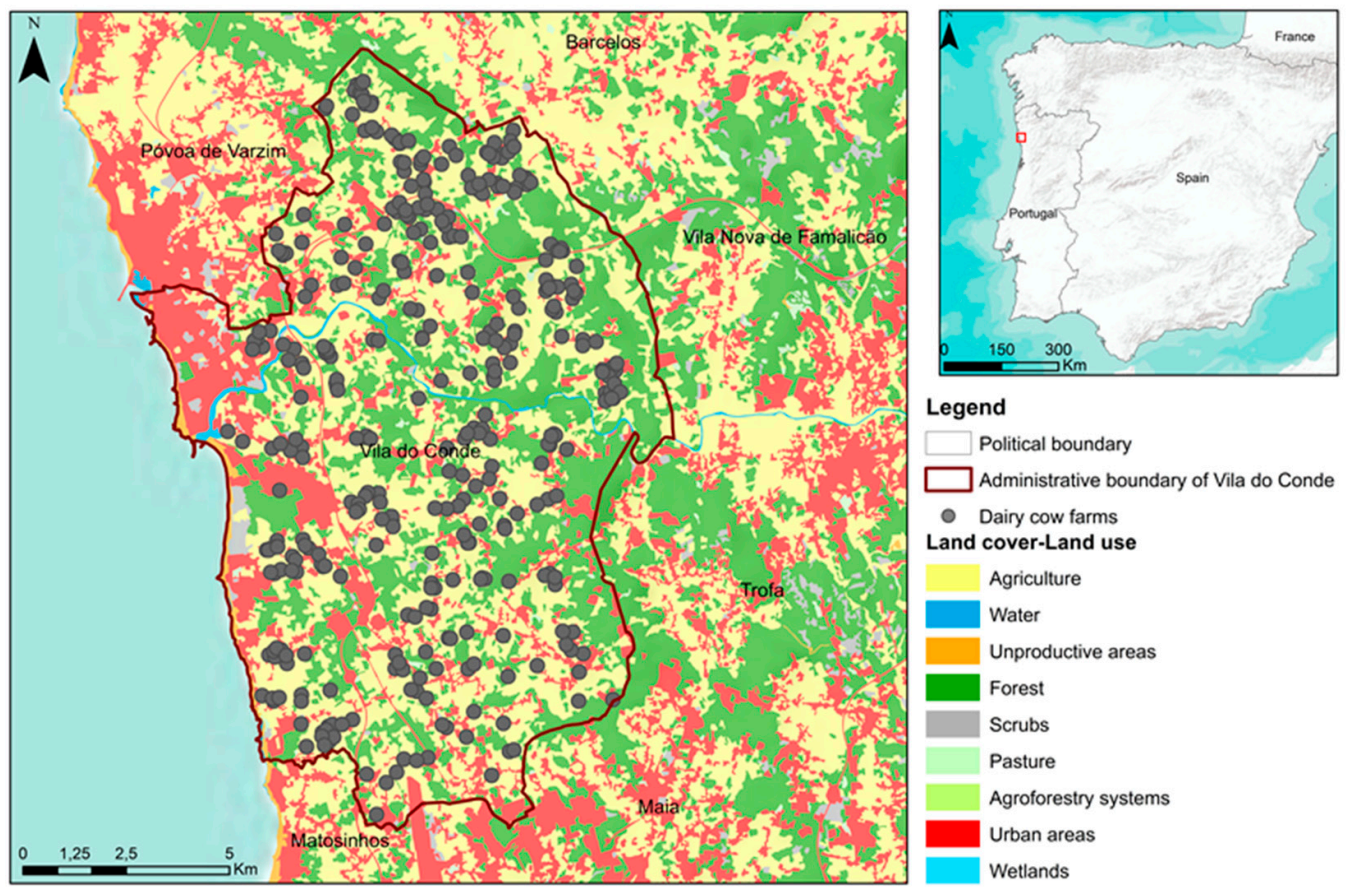

Figure 1. Spatial research unit of Vila do Conde municipality (NW Portugal). 
This process assumes that the location and pre-dimensioning of the biogas production units result from the collaboration among decision makers, project promoters, researchers (in environmental and spatial technologies) and technicians involved in land use planning and urban/(agro)industrial waste and wastewater facility development. The analyses and solutions consider: (i) the legal and regulatory framework (European directives, national legislation and national strategies); (ii) local/ sectorial planning and management framework; (iii) experimental data related to AcoD kinetic parameters [29]; and other (inter)national reference technical and scientific studies.

\subsection{Spatio-Temporal Patterns of Sewage Sludge and Dairy Cattle Manure Production and Availability}

The studies of optimization of the ACoD process [29] allowed the collection of indicators, knowledge and solutions in physical, chemical and biological processes that support the development of a spatially explicit location model. The analysis and estimation of production, availability and exploitability patterns of waste sludge from WWTPs and cattle manure from urban areas and dairy cattle farms consider: (i) current and future population distribution and economic activity [42]; and (ii) local cattle dairy farms' productive structure and the cows' spatial distribution [36].

Waste production pattern definition considers the average values of total solids (TS) production for sewage sludge $\left(16.5 \mathrm{~kg}_{\text {inhab }}{ }^{-1}\right.$ year $\left.^{-1}\right)$ [43] and for cattle dairy farms (20 $\mathrm{m}^{3} \mathrm{cow}^{-1}$ year $^{-1}$ with $3.5 \%$ of dry matter (TS) $\mathrm{m}^{-3}$ after solid-liquid manure separation) $[36,44,45]$. Results obtained from former studies [29] are also considered, such as the average ratio between total solids and volatile solids (VS) (65\%), the biogas yield $\left(93.3 \mathrm{~mL} \mathrm{gVS}^{-1}\right)$ and methane yield $\left(48.5 \mathrm{~mL} \mathrm{gVS}^{-1}\right)$. The models also consider the biogas calorific value of $21.5 \mathrm{MJ} \mathrm{m}^{-3}$ (electric energy content equivalent of $6 \mathrm{kWh} \mathrm{m}^{-3}$ and heat energy content equivalent of $2 \mathrm{kWh} \mathrm{m}^{-3}$, approximately) [46-49].

The present exercise considers the potential dynamics concerning production pattern changes, as well as the need for sewage sludge and cattle manure treatment and valorization according to the population and urbanization growth and sustainability of dairy farms $[37,50]$. To estimate the potential of biogas production, an estimate of the total amount of sewage sludge and cattle manure produced in the municipality of Vila do Conde was considered. Moreover, besides biogas production, sewage sludge and dairy cattle anaerobic co-digestion produce a digestate suitable for use as fertilizer [35], improving crops' productive capacity and reducing potential environmental impacts resulting from inappropriate disposal [51-54].

\subsection{Spatial Multicriteria Model Development to Support Biogas Facilities Location}

Multicriteria and multiobjective evaluation allows unit location and resource allocation spatial assessment processes by structuring decision problems. Different location studies of bioenergy production facilities use spatial multicriteria decision methodologies [22,24,37-39,55-60], with emphasis on fuzzy spatially explicit multicriteria decision systems using AHP [61-63], followed by multiobjective analysis [23] and associated resource allocation $[24,41,64,65]$.

Criteria spatial modelling and its analytical hierarchical process aims to find suitable locations. A multiobjective analysis ensures comparison between candidate location criteria and models, as well as alternative locations. These models and methods help decision makers to categorize decision problems logically by considering the land use options, legal framework, and stakeholders' perspectives and complementary/conflicting preferences [35]. The evaluation process requires criteria weighting, reasonability, gradual detail and multidisciplinarity in environmental technology themes, spatial science and economy.

The developed spatial model integrates operations of distance analysis, overlap, interpolation, reclassification, 3D surface analysis and network analysis, and technical and political options regarding the following aspects: (i) social aspects (service level, acceptance, social innovation; (ii) economic dimensions (related to investment, maintenance and operation costs) [66]; (iii) and environmental conditions (environmental impact and 
management towards environmental protection) (Table 1). Each criterion and dataset is standardized in spatial reference systems (ETRS89 TM06), and final thematic criteria values were reclassified into categorical scales ( 0 for exclusion, and a scale from 1 , low value, to 5 , optimal value) (Table 1$)$.

Table 1. Social, economic and environmental criteria and spatial analysis included in fuzzy multicriteria spatially explicit model.

\begin{tabular}{|c|c|c|c|c|c|}
\hline \multicolumn{2}{|c|}{ Criteria } & Spatial Analysis & Reclassify & Data Source & $\begin{array}{l}\text { Analytic Hierarchy } \\
\text { Process (AHP) } \\
\text { (value \%) }\end{array}$ \\
\hline \multirow{5}{*}{ 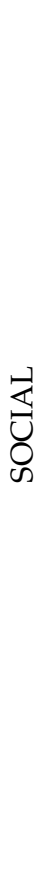 } & $\begin{array}{l}\text { Land Cover/ } \\
\text { Land Use }\end{array}$ & $\begin{array}{l}\text { Distance (m), } \\
\text { Reclassify; Overlay } \\
\text { (land use planning) }\end{array}$ & $\begin{array}{l}\text { (Forest 5; semi-natural 4; } \\
\text { Agriculture 1; Urban e } \\
\text { Water 0) }\end{array}$ & $\begin{array}{l}\text { Portuguese land } \\
\text { cover/land use } \\
\text { database (COS 2015) }\end{array}$ & 19.60 \\
\hline & Urban areas & $\begin{array}{l}\text { Distance }(\mathrm{m}) \text {, } \\
\text { Reclassify; (land use } \\
\text { planning; social } \\
\text { sensibility) }\end{array}$ & $\begin{array}{l}(0-250 \mathrm{~m}-0 ; 250-500 \mathrm{~m}-1 ; \\
500-750 \mathrm{~m}-2 ; 750-1000 \mathrm{~m}- \\
3 ; 1000-1250 \mathrm{~m}-4 ; \\
>1250 \mathrm{~m}-5)\end{array}$ & $\begin{array}{l}\text { Portuguese land } \\
\text { cover/land use } \\
\text { database (COS 2015), } \\
\text { Municipal Land Use } \\
\text { Masterplan (PDM) }\end{array}$ & 19.30 \\
\hline & $\begin{array}{l}\text { Industrial areas } \\
\text { distance }\end{array}$ & $\begin{array}{l}\text { Distance }(\mathrm{m}) \text {, } \\
\text { Reclassify; (land use } \\
\text { planning; social } \\
\text { sensibility) }\end{array}$ & $\begin{array}{l}(0-250 \mathrm{~m}-5 ; 250-500 \mathrm{~m}-4 ; \\
500-750 \mathrm{~m}-3 ; 750-1000 \mathrm{~m}- \\
2 ;>1000 \mathrm{~m}-0)\end{array}$ & $\begin{array}{l}\text { Portuguese land } \\
\text { cover/land use } \\
\text { database (COS 2015) }\end{array}$ & 25.90 \\
\hline & Forest areas & $\begin{array}{l}\text { Distance }(\mathrm{m}) \text {, } \\
\text { Reclassify; (land use } \\
\text { planning; social and } \\
\text { visual impact) }\end{array}$ & $\begin{array}{l}(0-250 \mathrm{~m}-5 ; 250-500 \mathrm{~m}-4 ; \\
500-750 \mathrm{~m}-3 ; 750-1000 \mathrm{~m}- \\
2 ; 1000-1250 \mathrm{~m}-1 ; \\
>1250 \mathrm{~m}-0)\end{array}$ & $\begin{array}{l}\text { Portuguese land } \\
\text { cover/land use } \\
\text { database (COS 2015) }\end{array}$ & 30.70 \\
\hline & Heritage Classifies & $\begin{array}{l}\text { Distance (m), } \\
\text { Reclassify; Overlay } \\
\text { (land use planning; } \\
\text { social and } \\
\text { environmental impact) }\end{array}$ & $\begin{array}{l}(0-250 \mathrm{~m}-0 ; 250-500 \mathrm{~m}-1 ; \\
500-750 \mathrm{~m}-2 ; 750-1000 \mathrm{~m}- \\
3 ; 1000-1250 \mathrm{~m}-4 ; \\
>1250 \mathrm{~m}-5)\end{array}$ & $\begin{array}{l}\text { Portuguese classified } \\
\text { heritage (IGESPAR) } \\
\text { and Municipal Land } \\
\text { Use Masterplan (PDM) }\end{array}$ & 4.40 \\
\hline \multirow{5}{*}{ 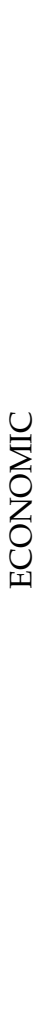 } & $\begin{array}{l}\text { Roads and Train } \\
\text { Network }\end{array}$ & $\begin{array}{l}\text { Distance (m), } \\
\text { Reclassify; Overlay; } \\
\text { network analysis (land } \\
\text { use planning; } \\
\text { economic costs) }\end{array}$ & $\begin{array}{l}(0-50 \mathrm{~m}-0 ; 50-500 \mathrm{~m}-5 ; \\
500-750 \mathrm{~m}-4 ; 750-1000 \mathrm{~m}- \\
3 ; 1000-1250 \mathrm{~m}-2 ; \\
>1250 \mathrm{~m}-1)\end{array}$ & $\begin{array}{l}\text { National Cartography } \\
\text { Series (SCN } 25 \text { k; } \\
\text { SCN } 10 \mathrm{k} \text { ) }\end{array}$ & 5.80 \\
\hline & $\begin{array}{l}\text { Energetic (electric } \\
\text { and gas network) }\end{array}$ & $\begin{array}{l}\text { Distance (m), } \\
\text { Reclassify; Overlay; } \\
\text { network analysis (land } \\
\text { use planning; } \\
\text { economic costs) }\end{array}$ & $\begin{array}{l}(0-250 \mathrm{~m}-5 ; 250-500 \mathrm{~m}-4 ; \\
500-750 \mathrm{~m}-3 ; 750-1000 \mathrm{~m}- \\
2 ; 1000-1250 \mathrm{~m}-1 ; \\
>1250 \mathrm{~m}-1)\end{array}$ & $\begin{array}{l}\text { National electric } \\
\text { Network (REN, EDP) }\end{array}$ & 9.00 \\
\hline & Farm Distance & $\begin{array}{l}\text { Distance (m), } \\
\text { Reclassify; Overlay; } \\
\text { network analysis (land } \\
\text { use planning; } \\
\text { economic and } \\
\text { social costs) }\end{array}$ & $\begin{array}{l}(0-250 \mathrm{~m}-5 ; 250-500 \mathrm{~m}-4 ; \\
500-750 \mathrm{~m}-3 ; 750-1000 \mathrm{~m}- \\
2 ; 1000-1250 \mathrm{~m}-1 ; \\
>1250 \mathrm{~m}-1)\end{array}$ & [36] & 24.30 \\
\hline & $\begin{array}{l}\text { Wastewater } \\
\text { Treatment units } \\
\text { (ETARS) distance }\end{array}$ & $\begin{array}{l}\text { Distance (m), } \\
\text { Reclassify; Overlay; } \\
\text { network analysis (land } \\
\text { use planning; } \\
\text { economic costs) }\end{array}$ & $\begin{array}{l}(0-250 \mathrm{~m}-5 ; 250-500 \mathrm{~m}-4 ; \\
500-750 \mathrm{~m}-3 ; 750-1000 \mathrm{~m}- \\
2 ; 1000-1250 \mathrm{~m}-1 ; \\
>1250 \mathrm{~m}-1)\end{array}$ & Águas de Portugal & 26.70 \\
\hline & $\begin{array}{l}\text { Bioenergy resource } \\
\text { availability density } \\
\text { (urban and rural) } \\
\text { Total Solid (TS) }\end{array}$ & $\begin{array}{l}\text { Density; } \\
\text { network analysis } \\
\text { (economic costs) }\end{array}$ & $\begin{array}{l}\left(0-100 \mathrm{~g} \mathrm{~m}^{-2}-1 ; 100-200 \mathrm{~g}\right. \\
\mathrm{m}^{-2}-2 ; 200-400 \mathrm{~g} \mathrm{~m}^{-2}-3 ; \\
400-600 \mathrm{~g} \mathrm{~m}^{-2}-4 ; \\
\left.>600 \mathrm{~g} \mathrm{~m}^{-2}-5\right)\end{array}$ & $\begin{array}{l}\text { National Cartography } \\
\text { Series (SCN } 25 \text { k; } \\
\text { SCN } 10 \text { k) }\end{array}$ & 34.20 \\
\hline
\end{tabular}


Table 1. Cont.

\begin{tabular}{|c|c|c|c|c|c|}
\hline \multicolumn{2}{|c|}{ Criteria } & \multirow{2}{*}{$\begin{array}{l}\text { Spatial Analysis } \\
\text { 3D surface analysis } \\
\text { (flood, soil water } \\
\text { content level) }\end{array}$} & \multirow{2}{*}{$\begin{array}{l}\text { Reclassify } \\
\begin{array}{l}(0-10 \mathrm{~m}-0 ; 10-40-5 ; 40-60- \\
4 ; 60-80-3 ; 80-100 \mathrm{~m}-2 ; \\
>100 \mathrm{~m}-1)\end{array}\end{array}$} & \multirow{2}{*}{$\begin{array}{l}\text { Data Source } \\
\text { National Cartography } \\
\text { Series (SCN 25 k, } 10 \mathrm{k} \text { ) } \\
\text { and Shuttle Radar } \\
\text { Topography Mission } \\
\text { (SRTM) }\end{array}$} & \multirow{2}{*}{$\begin{array}{l}\begin{array}{l}\text { Analytic Hierarchy } \\
\text { Process (AHP) } \\
\text { (value \%) }\end{array} \\
\\
\\
\\
\end{array}$} \\
\hline \multirow{7}{*}{ 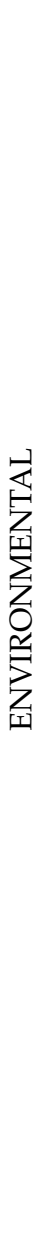 } & $\begin{array}{l}\text { Digital Terrain } \\
\text { Model (Altimetry) }\end{array}$ & & & & \\
\hline & Lithology and Soils & $\begin{array}{l}\text { Distance }(\mathrm{m}), \\
\text { Reclassify; Overlay } \\
\text { (Permeability, stability } \\
\text { and productivity) }\end{array}$ & $\begin{array}{l}\text { (Fluvissoils- 1; } \\
\text { Cambissoils- 4; } \\
\text { Regossoils-3; Lepstosoils 5; } \\
\text { Antrossoils- 0, Water- 0; } \\
\text { Urban- 0) }\end{array}$ & $\begin{array}{l}\text { Soil capacity and Soil } \\
\text { suitability database } \\
\text { (Carta de Solos e } \\
\text { Aptidão da Terra do } \\
\text { Entre Douro e Minho) }\end{array}$ & 14.70 \\
\hline & $\begin{array}{l}\text { Hydrography and } \\
\text { water areas } \\
\text { (superficial and } \\
\text { sub terrain) }\end{array}$ & $\begin{array}{l}\text { Distance }(\mathrm{m}), \\
\text { Reclassify; Overlay } \\
\text { (Public hydric domain) }\end{array}$ & $\begin{array}{l}(0-20 \mathrm{~m}-0 ; 20-50 \mathrm{~m}-1 ; \\
50-100 \mathrm{~m}-2 ; 100-150 \mathrm{~m}-3 \\
150-200 \mathrm{~m}-4 ;>200 \mathrm{~m}-5)\end{array}$ & $\begin{array}{l}\text { National Cartography } \\
\text { Series (SCN } 10 \mathrm{k} \text { ); } \\
\text { Water Framework } \\
\text { Directive (WFD) and } \\
\text { River basin Plans } \\
\text { (APA, PGRH) }\end{array}$ & 16.0 \\
\hline & $\begin{array}{l}\text { Environmental } \\
\text { Protected and } \\
\text { Classified Areas }\end{array}$ & $\begin{array}{l}\text { Distance (m), } \\
\text { Reclassify; Overlay } \\
\text { (land use planning) }\end{array}$ & $\begin{array}{l}(0-20 \mathrm{~m}-0 ; 20-50 \mathrm{~m}-1 ; \\
50-100 \mathrm{~m}-2 ; 100-150 \mathrm{~m}-3 ; \\
150-200 \mathrm{~m}-4 ;>200 \mathrm{~m}-5)\end{array}$ & $\begin{array}{l}\text { Portuguese } \\
\text { environment national } \\
\text { Agency (APA) }\end{array}$ & 31.50 \\
\hline & $\begin{array}{l}\text { National } \\
\text { Ecological Reserve }\end{array}$ & $\begin{array}{l}\text { Distance (m), } \\
\text { Reclassify; Overlay } \\
\text { (land use planning) }\end{array}$ & $\begin{array}{l}(0-20 \mathrm{~m}-0 ; 20-50 \mathrm{~m}-1 ; \\
50-100 \mathrm{~m}-2 ; 100-150 \mathrm{~m}-3 ; \\
150-200 \mathrm{~m}-4 ;>200 \mathrm{~m}-5)\end{array}$ & $\begin{array}{l}\text { Municipal Land Use } \\
\text { Masterplan (PDM) }\end{array}$ & 15.70 \\
\hline & $\begin{array}{l}\text { National } \\
\text { Agricultural } \\
\text { Reserve }\end{array}$ & $\begin{array}{l}\text { Distance (m), } \\
\text { Reclassify; Overlay } \\
\text { (land use planning) }\end{array}$ & $\begin{array}{l}\text { (Interior } 0-20 \mathrm{~m}-1 ; 20-50 \\
\mathrm{~m}-2 ; 50-100 \mathrm{~m}-3 ; 100-150 \\
\mathrm{~m}-4 ; 150-200 \mathrm{~m}-5 ; \\
>200 \mathrm{~m}-6)\end{array}$ & $\begin{array}{l}\text { Regional Agriculture } \\
\text { Administration } \\
\text { (DRAPN), Municipal } \\
\text { Land Use } \\
\text { Masterplan (PDM) }\end{array}$ & 10.10 \\
\hline & $\begin{array}{l}\text { Geological risks } \\
\text { areas }\end{array}$ & $\begin{array}{l}\text { 3d Surface, Reclassify, } \\
\text { Distance; Overlay Risk } \\
\text { Modelling }\end{array}$ & $\begin{array}{l}\text { Without risk- 5; Low risk- } \\
\text { 3; Moderate Risk- } 1 \text {; High } \\
\text { risk- } 0\end{array}$ & & 3.40 \\
\hline
\end{tabular}

These criteria include: (i) critical aspects of natural suitability, distance and accessibility; (ii) social conditions associated with collective acceptance and potential economic and environmental viability; (iii) risk reduction objectives, by imposing distances to watercourses, coastlines, and ecologically and agriculturally sensitive areas considering geological risks; and (iv) other aspects relevant to the economy, such as distance to the electrical grid, roads and land surface analysis (Table 1 ).

The collection, management and analysis of spatial data, which inform each criterion, involved metadata production (ISO19115 and 19139 profiles), data modelling (INSPIRE spatial data specification), spatial analysis and database quality assessment (ISO19157 and ISO19158) [25]. Criteria reclassification and standardization precede the weighted overlay (AHP) product to establish reclassification criteria of continuous values of the suitability map regarding finding/assigning adequate locations for biogas facilities.

The AHP approach is a flexible decision-making tool for determining the relative importance, preference or likelihood of occurrences considered by users (decision makers, researchers, entrepreneurs and population) by comparing criteria pairs [67]. Peer comparison helps decision makers to evaluate the contribution of each criterion or factor to the objective, in an independent and simple way. In this study, the AHP allowed the ranking and weighting of the relative importance of the different factors/criteria in the final results [22]. Final values were obtained based on the 9-point classification system described by [67], with consistency coefficients (CC) with values below 0.10 being accepted. 


\subsection{Multicriteria Model Validation, Resources Allocation and Biogas Plants Pre-Dimensioning}

The validation of the results includes the observation of potential locations for biogas production facilities using photointerpretation and an in-field survey complemented by sensitivity analysis. Sensitivity analysis was performed by changing the total weighting of the products of environmental, social and economic criteria $(+/-20 \%)$ and assessing their impact on final location suitability results of biogas facilities.

Comparative analysis of alternative location solutions (associated with pre-dimensioning) considers management models and objectives of collective biogas units. Multiobjective and pre-dimensioning analysis considers alternative scenarios (centralized considering 1 to 3 biogas production facilities or distributed biogas production systems, from 5 to 8 new units) related to the number and biogas plants dimension (considering the amount of sewage sludge and dairy cattle manure available). The new potential resource allocation resulted in areas with very high (optimum), high or medium biogas facility location suitability. In this phase, the alternative scenarios considering the minimum area of influence required and available for each existing and new biogas production unit were also explored.

Considering modelling and simulation possibilities and different alternative scenario systems, as examples, biogas plant location in suitable areas precedes the definition of biogas facilities and influences areas using road network analysis tools, namely exploring hot spot analysis as well as Thiessen polygons spatial analysis [68]. Location-allocation analysis and p-median problem [69] intend to find optimum locations of facilities such that the product of the (weighted) distance and impedance between each demand location and the nearest facility is minimized, as well as allowing test and maximize couverture [70].

These new polygons allow the use of overlay operations aiming to estimate the allocation of feedstock based on sewage sludge and cattle manure availability and associated biogas plant capacity $\left(\mathrm{m}^{3}\right.$ biogas year $\left.{ }^{-1}\right)$ to the resulting potential electric and heating energy. These data also allowed us to generate spatial cluster analysis to optimize the location within each influence polygon (area), considering the geographical distance between units and the spatial resource distribution (sewage sludge and cattle manure).

\subsection{Multicriteria Spatially Explicit Model Development}

Multicriteria model validation, the location selection and the pre-dimensioning (based on resource allocation and bioenergy potential) of biogas production facilities support the results presentation and scientific and technical discussion. A final critical evaluation of the methodological approach and results was carried out, followed by proposal definition in order to transform the research products into thematic and spatial decision support tools at future biogas production facilities' project and management phases.

\section{Results}

\subsection{Unit Area, Research Scope and Challenges}

Vila do Conde municipality (149.03 $\mathrm{km}^{2}$ and 79,533 inhabitants in 2011) is located on the north-west coast of Portugal, in the lower third section of the Ave river, occupying both riverside and the Atlantic coastal region (Figure 1). Natural conditions and existing infrastructures provide favorable conditions for socioeconomic development, with increasing population density and the growth of peri-urban areas [1,71]. The mild climate conditions associated with water and soil with high chemical, physical and biological quality favor the suitability for agroforestry activities and the intensification, concentration and specialization of dairy cattle farms [36]. These territorial interface urban-rural areas encompass important environmental issues concerning air, soil, water and landscape quality, as well as social and economic conflicts between the rural and urban populations [36].

To overcome these territorial planning and management challenges, it is necessary to integrate areas and human activities, innovating in transport and energy supply/consumption solutions as well as in decision support [37] and governance systems [36]. The development and use of new technologies, efficient processes and local organizational 
solutions foster bio-based and circular economy dynamics [37] towards an improvement in the quality of life and of the local environment [50,72].

\subsection{Sewage Sludge and Cattle Manure Spatio-Temporal Patterns}

The resident population (in Vila do Conde municipality) increased as a result of local and regional improvements in accessibility to the closest Oporto metropolitan area (NW Portugal). The population concentration in coastal, riverside and near highway main accesses, as well as near industrial areas and the services sector, results in a considerable increase in the current and potential distribution dynamics of municipal waste and sewage sludge (Figure 2).

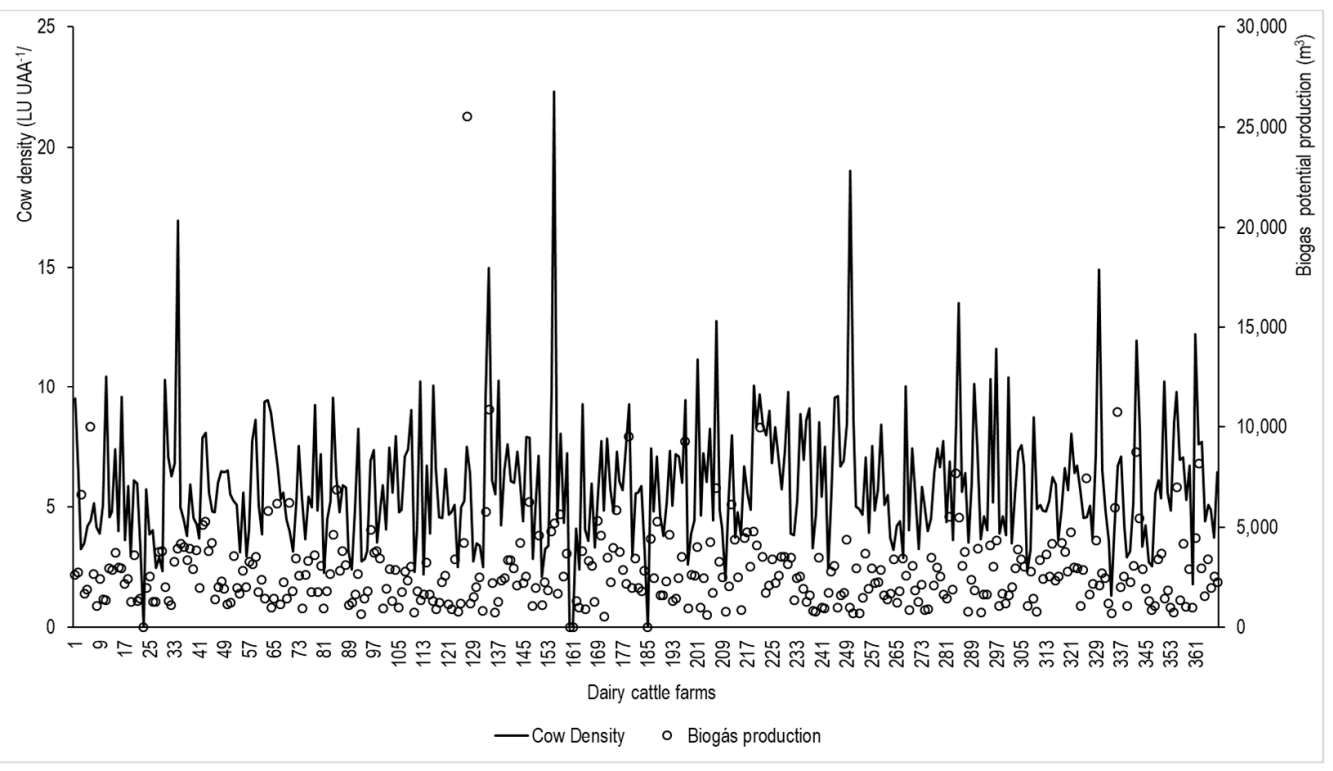

Figure 2. Number of cows and biogas potential production $\left(\mathrm{m}^{3}\right)$ per dairy cattle farm.

The 368 dairy cattle local farms present distinct physical, economic and social dimensions (between 13 and 620 cows, mean of 67 cows per farm) (Figure 2) using semi-intensive production systems with a variety of production technologies, namely concerning the type of farm buildings, existing farm machinery equipment, and usual practices for waste and wastewater collection, storage, treatment, valorization and nutrient/energy recovery [36]. Hence, several challenges arise regarding the optimization of manure production and management systems in individual or collective solutions. Despite this variability, most farms are small (under 50 cows per farm), with limited economic and social resource capacity to invest and support individual waste and/or wastewater treatment systems for energy and nutrient recovery $[36,37,45,50,72]$.

The small productive area and limited investment capacity of most dairy cattle farms are associated with legal constraints resulting from agricultural and environmental policies and directives, e.g., animal welfare [72] and food safety, farm licensing requirements, the Nitrates Directive and the Water Framework Directive, which pose significant challenges to these animal production units' adaptation and sustainability. Furthermore, cattle manure production and management in dairy cattle production units, in association with the increasing social pressure of the urban population, pose additional barriers to achieve sustainable solutions for these dairy cattle farms. In Vila do Conde, dairy farms are distributed in the territory, but a higher density is observed in areas with soil suitable for agriculture, such as in the main Ave River basin and the Este River sub-basin. The farms with a higher number of animals or higher animal to area ratio present higher potential to produce biogas (Figure 2).

The results indicate that sewage sludge and dairy cattle manure production present different spatial and temporal patterns. Municipal wastewater is distributed according to con- 
centrated, dispersed and regular urban areas, with lower average unit values. The sewage sludge is collected in wastewater treatment plants, and in Vila do Conde municipality, the urban sanitation system includes a WWTP with an anaerobic digester producing biogas. Cattle manure has a diffuse distribution associated with production and storage sites as well as associated animal forage/feed productions. This spatial distribution pattern is associated with the high density of dairy cattle farms, animals and dairy cattle manure in crop and peri-urban areas (spatial groups) (Figure 3). Actually, current cattle manure production does not correspond to current and real availability and exploitability for biogas production.

According to the approved or under development cattle manure management plans, most farmers use 50 to $80 \%$ of the cattle manure as fertilizer in their vegetal and crop production [36]. Thus, bioenergy recovery processes, such as ACoD, as an individual or collective treatment and valorization strategy of cattle manure and sewage sludge, associated with other resource recovery technologies (e.g., composting and/or struvite precipitation), gained increasing attention considering the complementary character of the processes, which lead to an improvement of local fertilization practices. Under the tested conditions, the available and modelled data showed that, in this case, a higher quantity is produced and available of dairy cattle manure than sewage sludge. This aspect may represent a challenge to the anaerobic co-digestion process if the proportion of substrates is maintained at 1:1 $(\mathrm{v} / \mathrm{v})$, as suggested by Coura [29].

\subsection{Environmental, Social and Economic Criteria in Biogas Plant Location}

From the spatial criteria selected, it is possible to highlight constraints regarding the location of biogas facilities in permeable, unstable and flooded soils (sand soils, riparian and coastal areas), in protected areas and within the ecological and national agricultural reserve network, in areas with high geological risks, low and high altitude, as well as in hydrographic protection areas that consider river network buffers, flooded areas and public hydric domains.

The results from social criteria application avoid the location of biogas facilities within or near urban areas and classified cultural heritage, and prefer locations near industrial zones and forested areas. Economic criteria consider as relevant the proximity to the existing biogas plant, the road network, the injection points in the electric grid network and adequate bioenergy resource availability (sewage sludge and cattle manure).

Environmental, social and economic criteria overlay and weighted product (AHP), followed by consistency and sensitivity analysis, indicate several suitable locations with low and medium altitude showing high suitability and adequate area requirements for collective biogas facility location (Figure 4). The results also pointed out a significant extension of exclusion areas, considering legal (e.g., master land use plans) and technical constraints (e.g., building implantations). Even when considering changes in weighting and the use of more restricted criteria (sensitivity analysis), it is possible to identify scattered locations with very high/optimum suitability and minimum area needs to locate biogas facilities (Figure 4). 


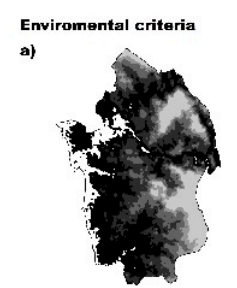

b)
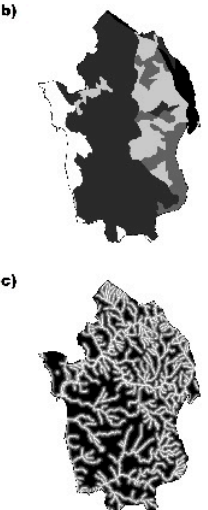

d)
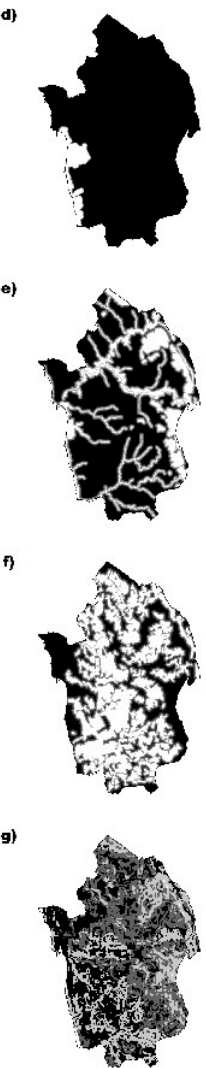
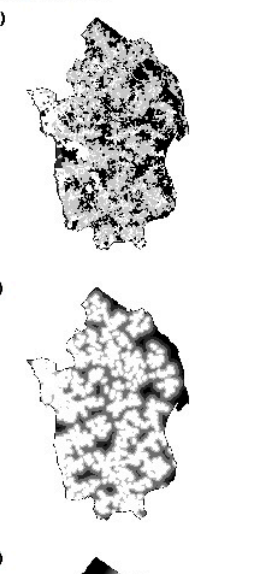

o)

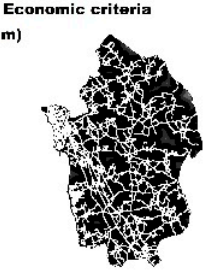

n)

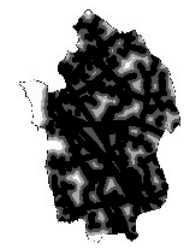

o)
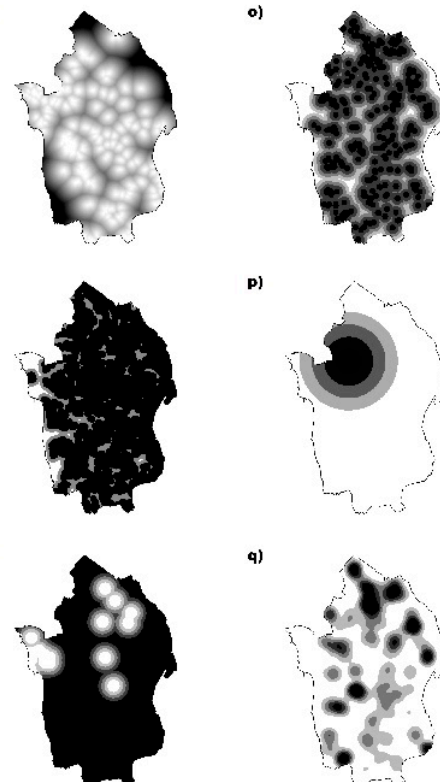

$0 \quad 10$

20

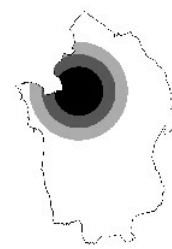

a)

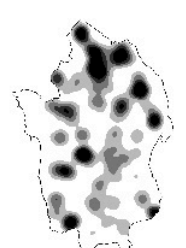

20 $40 \mathrm{Km}$

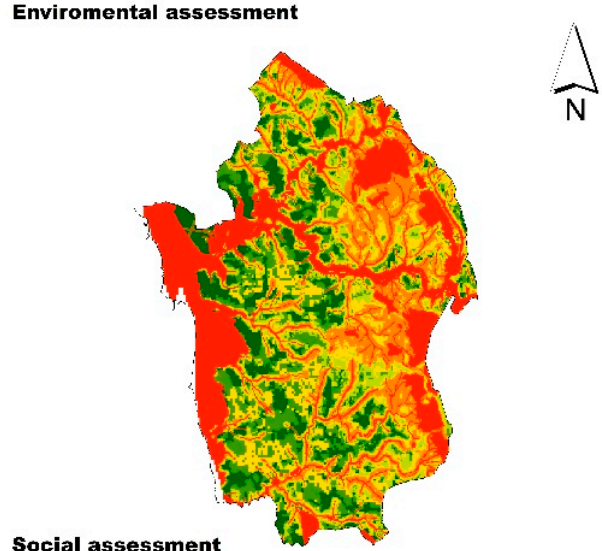

Social assessment

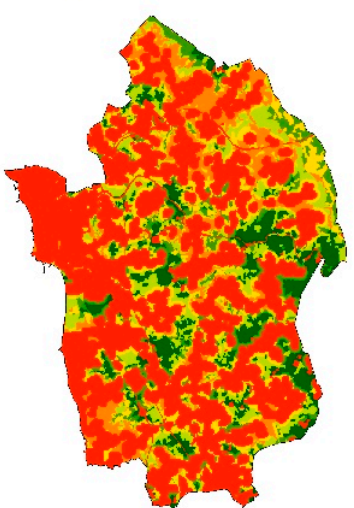

Economic assessment

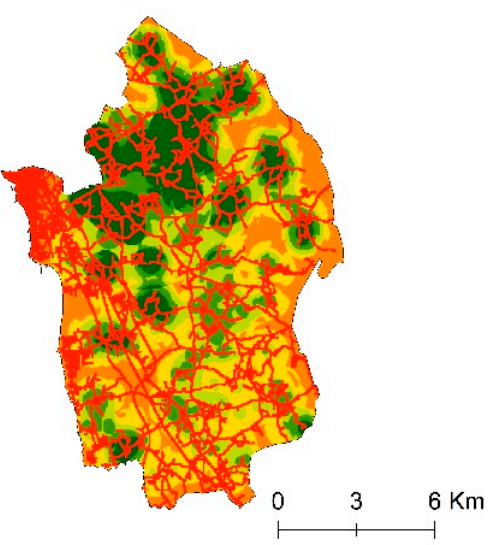

Suitability criteria

High : 5

Low : 0

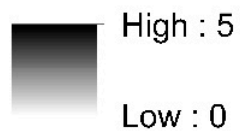

Suitability assessment

\begin{tabular}{ll|l}
\hline Exclusion zone & & Medium \\
Very low & High \\
\hline Low & Very high
\end{tabular}

Figure 3. Environmental, social and economic multicriteria in spatial explicit model development: (a) Digital terrain model (altimetry); (b) Lithology and soils; (c) Hydrography and water areas (superficial and sub terrain); (d) Environmental protected and classified areas; (e) National ecological network; (f) National agriculture network; (g) Geological risks areas; (h) Land cover/Land use; (i) Urban areas; (j) Industrial area distance; (k) Forest areas; (1) Cultural heritage classified; (m) Roads and train; (n) Network energetic (electric and gas network/PIP); (o) Farm distance; (p) Wastewater treatment plant distance; (q) Bioenergy resource availability density (urban and rural). Environmental, social and economic assessment resulting from weighted sum from each criterion. 

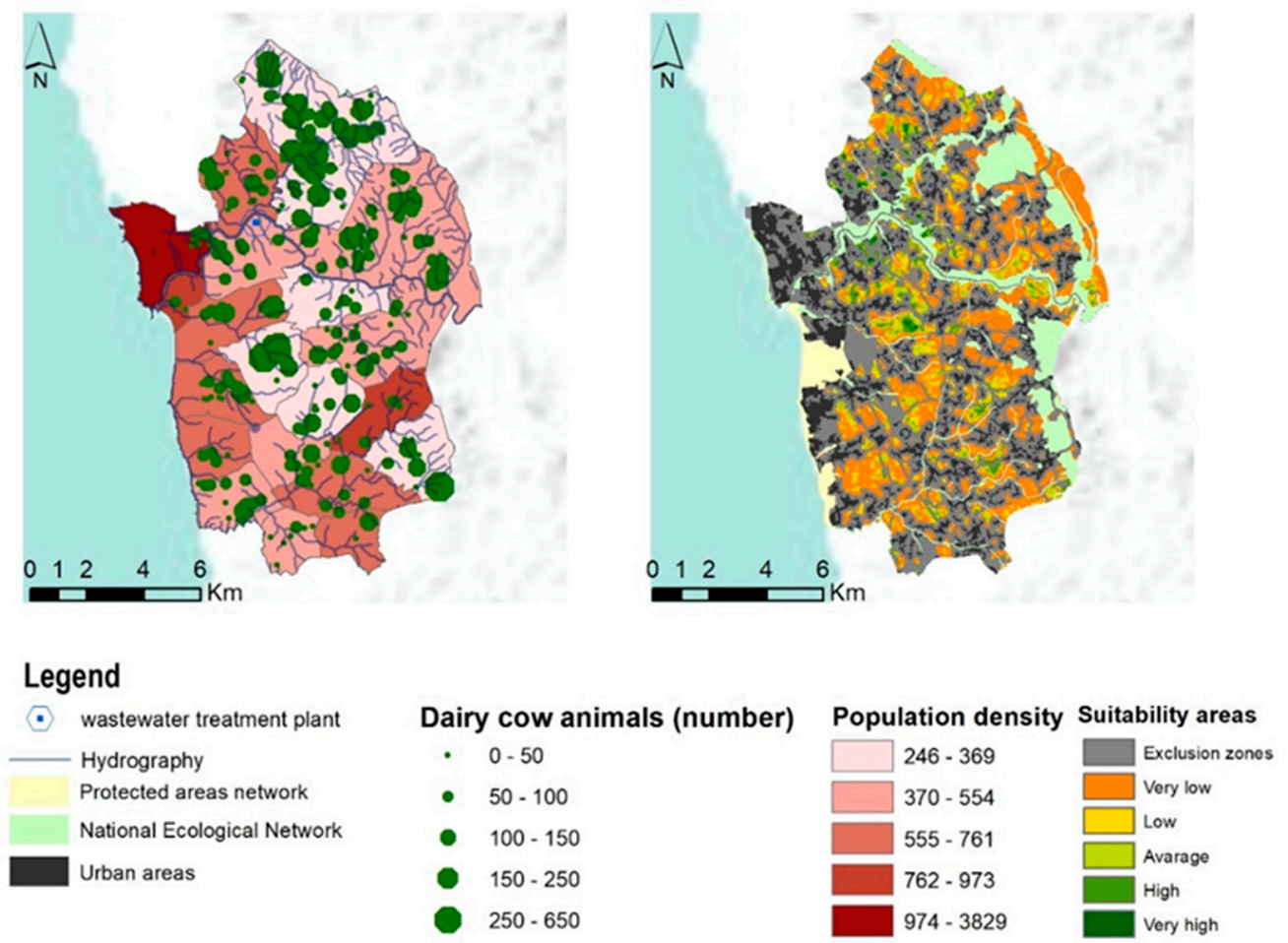

Figure 4. Population density (inhabitants $\mathrm{km}^{-2}$, dairy cattle farms (number) and biogas production facility location suitability.

\subsection{Biogas Facilities' Location, Resources Allocation and Pre-Dimensioning}

The modelling results refer to adequate local potential for the implementation of ACoD biogas production facilities considering local conditions, resources' spatiotemporal availability and the technical indicators about $\mathrm{ACoD}$ conversion processes and biogas caloric value (Table 2). The referred data obtained in biogas production at a laborato$\mathrm{rial} / \mathrm{pilot}$ scale were considered in a resource availability assessment, in location analysis and the pre-dimensioning of the potential biogas production facilities.

Table 2. Indicators adopted in the case study.

\begin{tabular}{|c|c|c|}
\hline Indicators & Value & Reference \\
\hline Volatile solids/Total solids (\%) & 65 & [29] \\
\hline Methane yield $\left(\mathrm{mL} \mathrm{gVS}^{-1}\right)$ & 48.5 & [29] \\
\hline Biogas yield (mL gVS $\left.{ }^{-1}\right)$ & 93.3 & [29] \\
\hline Average methane content $(\%)$ & 52 & [29] \\
\hline Biogas calorific value $\left(\mathrm{MJ} \mathrm{m}^{-3}\right)$ & 21.5 & [47] \\
\hline Waste sludge production (kg TS capita ${ }^{-1}$ year $^{-1}$ ) & 16.4 & [43] \\
\hline
\end{tabular}

Improving biogas production processes (biogas quantity and quality) through the $\mathrm{ACoD}$ of different substrates increases the potential return and competitiveness of these processes, relative to other alternative resource recovery technologies.

The spatially explicit model indicates a unique centralized biogas plant as a possible solution (Figure 5b), but also allows us to explore several scenarios/simulations regarding the number of facilities, dimension and location according to a multiobjective framework. In this context, as an example, two different scenarios were developed, i.e., decentralized systems with eight biogas facilities (Figure 6a) and centralized systems with five biogas production facilities (Figure $6 b$ ). 

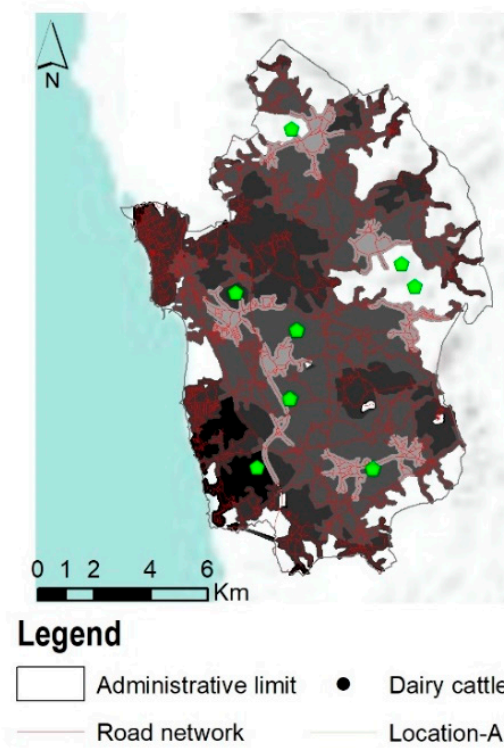

(a)

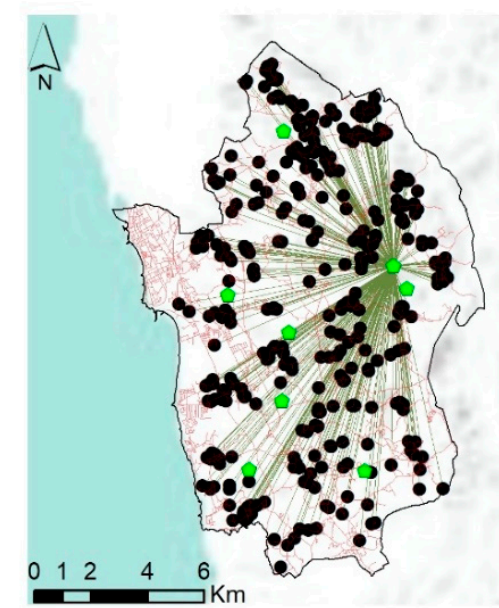

(b)

Distance to facilities

- Dairy cattle farms
Location-Alocation line

$\begin{array}{rl}2000 \mathrm{~m} & 6000 \mathrm{~m} \quad \text { Biogas unit plants } \\ 4000 \mathrm{~m} & 8000 \mathrm{~m}\end{array}$

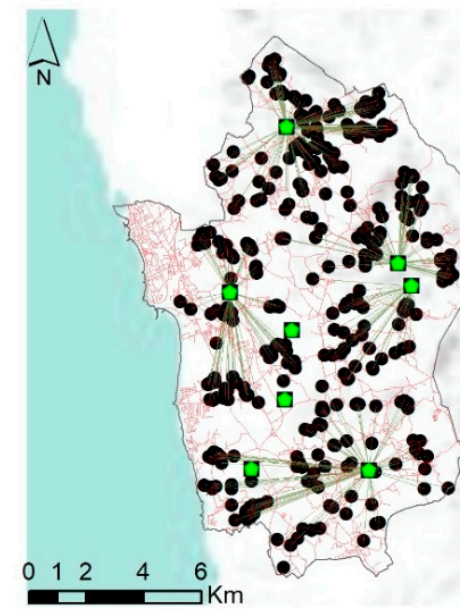

(c)

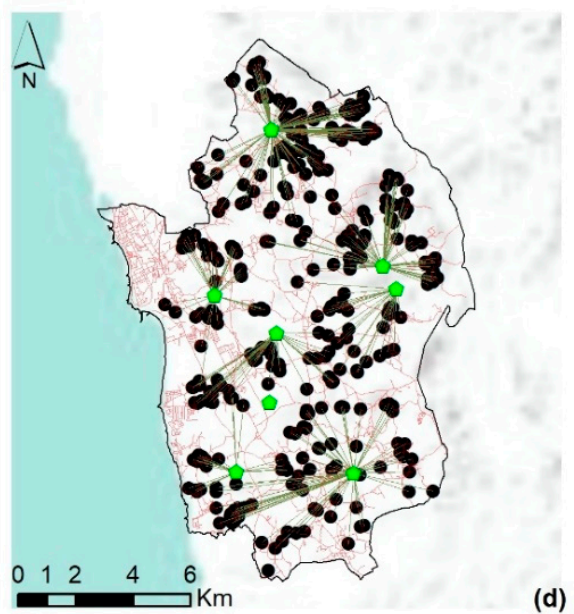

Legend

Administrative limit $\quad$ Road network

- Biogas unit plants

- Dairy cattle farms

Location-Alocation line

Figure 5. (a) Distance road analysis (m) to biogas plants; (b) Allocation analysis considering centralized (1 biogas facility); (c,d) distributed scenarios (5 and 8 facilities).

Local urban sewage sludge availability ( 853 tonVS year $^{-1}$ ) and dairy cattle manure $\left(10,970\right.$ tonVS year $\left.{ }^{-1}\right)$ refer to a potential for biogas $\left(1,102,773 \mathrm{~m}^{3}\right.$ year $\left.^{-1}\right)$, methane $\left(573,441 \mathrm{~m}^{3}\right.$ year $\left.^{-1}\right)$, heat $(7,046,717 \mathrm{kWh})$ and electric energy $(2,205,545 \mathrm{kWh})$ production. The distributed system scenario revealed a maximum biogas production potential in the range of $70,000-320,000 \mathrm{~m}^{3}$ per facility per year. Assuming the indicators described in Table 2, the referred biogas potential production is equivalent to approximately $447,300-204,000 \mathrm{kWh}$ of heat energy or 140,000-640,000 kWh of electrical power (Figure 6) per facility per year. In contrast, the centralized scenario indicates a maximum biogas potential production between 265,000 and $390,000 \mathrm{~m}^{3}$ per facility per year, which is equivalent to $1,600,000-2,600,000 \mathrm{kWh}$ of heat energy or $500,000-800,000 \mathrm{kWh}$ of electrical power. In the development, one of the centralized system scenarios (three biogas plants), which considered the existing WWTP biodigester (ETAR do Ave, Tougues), requires the construction of two new facilities (Figure 6). 

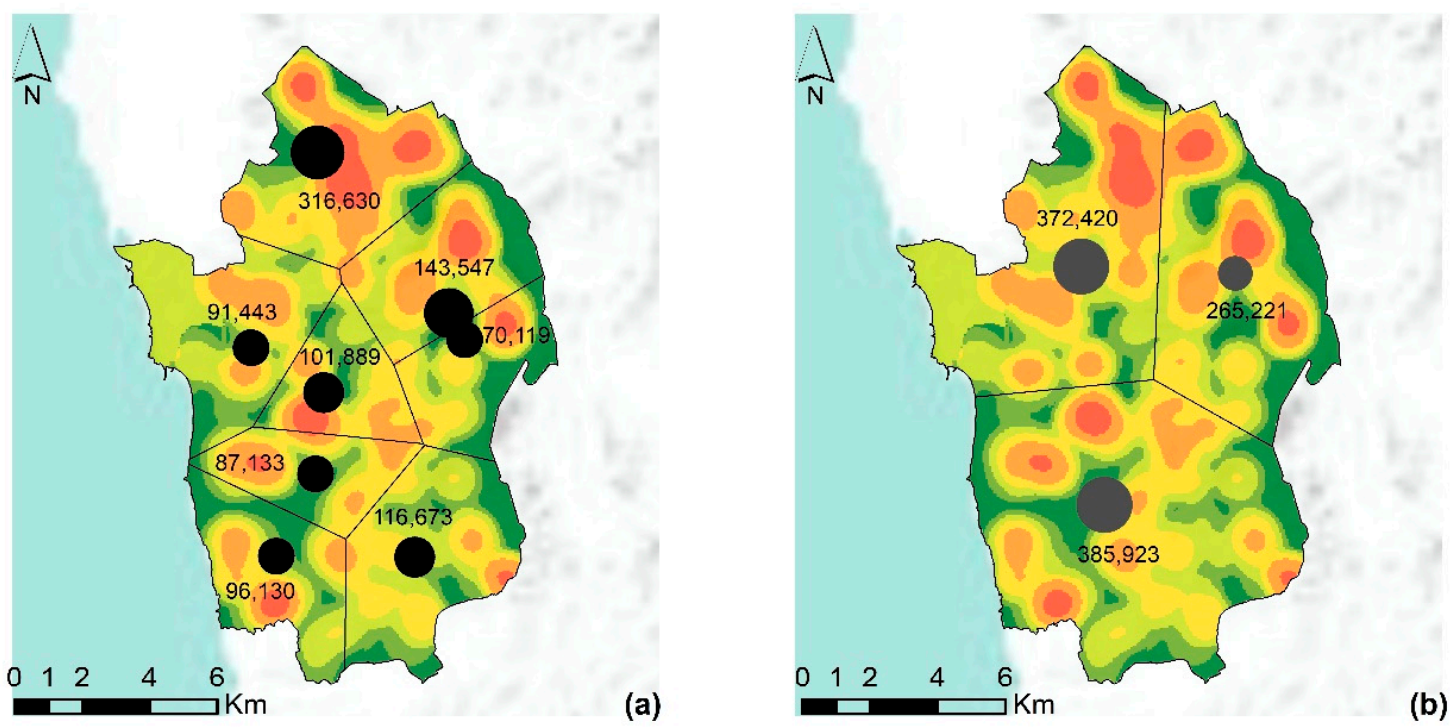

\section{Legend}

$\square$ Thiessen polygons Biogas influence areas

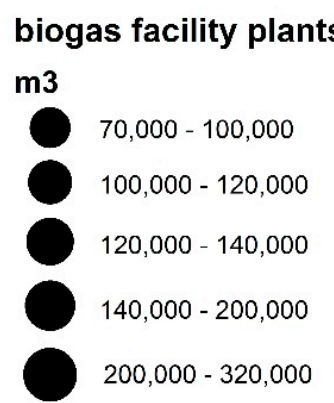

(a)
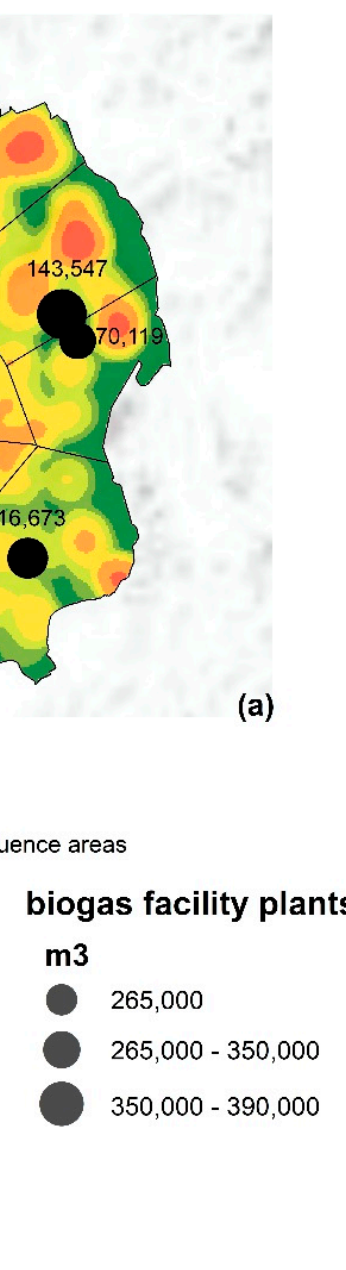

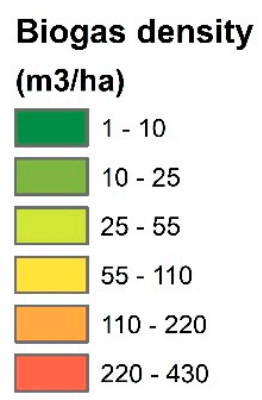

Figure 6. Resource Allocation, Areas of Influence and Energy Capacity of the Biogas Facilities in the Two Scenarios.

These solutions considered different alternative projects and future biogas facility management models. Centralized system solutions reduce the initial investment, but reinforce the complexity and the costs of operation. According to [73], centralized treatment plants have a significantly higher overall payload distance, which supports the idea of a higher transport efficiency of a decentralized system compared to a centralized one [74], even in a territory with a high density of urban and peri-urban areas [73].

The present exercise and results also indicate the possibility of ensuring sectorial and territorial complementarity between urban and rural systems by assuming the adaptation of existing sanitation systems under territorial agreements/partnerships and innovative governance model frameworks. The spatially explicit model and the developed method can be tested and adjusted to other assumptions of the quantity, distribution and exploitability of available resources, as well as process changes/improvements and biogas production yields, in terms of quantity and quality (i.e., methane content in biogas). The calculated values refer to annual averages. However, not only due to the seasonable fluctuations in the resident population of Vila do Conde municipality, but also due to the seasonal character of dairy cattle manure availability, it is important to detail the temporal (seasonal) variability as well as to adapt the expected future evolution/dynamics of production, resource availability and associated allocation.

\section{Discussion}

Scientific and technological advances concerning bioenergy system plants' operation and the optimization of waste treatment and valorization result in knowledge with a major 
role to improve decision models regarding the location (at local or regional scale) and allocation resources to biogas facilities. The complex and dynamic nature of biogas production facility location, resources allocation and pre-dimensioning analysis requires multicriteria spatial models that consider environmental (protection), social (responsibility and safety) and economic (viability) criteria [75], as well as conflicting and alternative location and allocation objectives, namely associated with centralized or distributed solutions.

The spatial, thematic, institutional and temporal scope of the study, as well as the selection of treatment and valorization systems, determines the issues, the nature and the development of the spatially explicit model. The developed approach and methods have a scale-based nature and are applicable to similar subjects, challenges and local spaces. The developed methodology and spatial model should consider changes in spatial and temporal patterns of available resources to produce bioenergy and process biogas yields. In this research, the biological treatment process kinetic indicators (Table 2) refer to the optimization of the AcoD of SwS and CMLF [29], but the model's versatile nature allows the use of different kinetic parameters. In that regard, studies about the optimization of the AcoD process including other organic wastes/agroindustrial wastewaters, such as cheese whey, winery wastewater, among others, should be performed in order to obtain the kinetic indicators most suitable to be integrated into the model. Each research work case assumes specificities concerning the representation and meaning of environmental, social and economic criteria and objectives within a dynamic local political, legal and technical/technologic framework. The implementation of a biogas production utility, as a very complex infrastructure, may include pre/post treatments and must consider the logistics of sludge disposal. These aspects were initially considered in this research (i.e., weighted overlay-AHP) and are a subject to be thoroughly detailed and assessed, considering econometric and logistic aspects in the project's further phase.

The definition, weighting and interpretation of sensitivity analysis resulting from the application of spatial criteria should assume a multidisciplinary, collaborative and inclusive nature. Results location validation from in-field data and modelling outputs are central/critical to the biogas facility project's further phases. These scenarios and potential resource allocation data are relevant to the next steps of biogas production facility dimensioning (i.e., to calculate investment and operating costs, as well as the technical and economic viability assessment of each new biogas facility).

\section{Conclusions}

The present research revealed the interest in incorporating data obtained from anaerobic co-digestion optimization and innovation processes (laboratorial scale) into the local territorial reality dynamics in the development of biogas production units' location and resource allocation scenarios, and implementing effective circular economy models and local sustainable development.

The modelling results pointed out that it is possible to set up the location of biogas plants based on resource availability and local biogas yield. Both data and the spatial model enable multidisciplinary approaches, analysis scale changes, actor coordination among the project/planning phases, as well as communication among stakeholders, technicians and the scientific community.

The developed spatial model indicates:

1. A high potential of local bioenergy resources available for biogas production (dairy cattle manure and sewage sludge) and the interest in complementing, at a local scale, the use of existing biogas producing facilities (including those integrated in wastewater treatment plants) with new collective facilities;

2. The suitable locations for the installation of biogas production facilities in low altitude, forested areas, near to cattle farms, the road network and electric injection points, but far from the hydrographic network and avoiding the ecological reserves and protected areas; 
3. The need to collect and analyze additional and detailed thematic and temporal (e.g., seasonal) data on sewage sludge and animal manure production;

4. The importance of developing multicriteria optimization algorithms to test a set of maximization and optimization functions (location and allocation issues), considering economic and econometric functions and objectives;

5. The reinforcement of multi-objective assessment to compare sites and alternative management models, considering investment and cost analysis.

This research has involved collaborative and multidisciplinary tasks in in-field work model validation and future work discussions. Both field collected data and the results of the spatially explicit model are critical to the biogas unit project phase, namely to project technological and constructive solutions within a local social, economic and environmental assessment framework for all and each new potential biogas plant/facility.

The results also showed the importance of continuing the development of this spatial model towards a spatial decision support system on a Web-Geographic Information System (WebGIS) platform supporting the planning and future operation of biogas production plants. Experience, data and the spatially explicit model should evolve as a planning, management and governance tool [76]. The integration of the laboratorial data, methods and models into the complex territorial dynamics promotes synergies by contributing to circular economy and the sustainable development of peri-urban communities.

Author Contributions: Conceptualization, R.D.C., J.M.A., A.C.R., A.I.F., A.G.B.; methodology, R.D.C., J.M.A., A.C.R., N.M., R.S.; validation, R.D.C., J.M.A., A.C.R., A.I.F., A.G.B.; investigation, R.D.C., J.M.A., A.C.R., A.I.F.; data curation, R.D.C., J.M.A., A.C.R., A.I.F., N.M., R.S.; writing-original draft preparation, R.D.C., J.M.A., A.C.R., A.I.F.; writing-review and editing, R.D.C., J.M.A., A.C.R., A.I.F., A.G.B.; visualization, R.D.C., J.M.A., A.C.R., A.I.F.; supervision, J.M.A., A.C.R., A.G.B.; funding acquisition, R.D.C., J.M.A., A.C.R., A.G.B. All authors have read and agreed to the published version of the manuscript.

Funding: This research was funded by the Conselho Nacional de Desenvolvimento Científico e Tecnológico (CNPq Brazil), grant number GDE 201469/2014-6.

Institutional Review Board Statement: Not applicable.

Informed Consent Statement: Not applicable.

Data Availability Statement: The data presented in this study are available on request from the corresponding author. The data are not publicly available due to legal (e.g., privacy) and ethical restrictions.

Acknowledgments: We greatly appreciate the support of the research units Geomatics and Environmental Systems Analyses of IPVC (Portugal) and Linking Landscape, Environment, Agriculture and Food (LEAF) of ULisbon (Portugal).

Conflicts of Interest: The authors declare no conflict of interest. The funders had no role in the design of the study; in the collection, analyses, or interpretation of data; in the writing of the manuscript, or in the decision to publish the results.

\section{References}

1. Winarso, H.; Hudalah, D.; Firman, T. Peri-urban transformation in the Jakarta metropolitan area. Habitat Int. 2015, 49, 221-229. [CrossRef]

2. Lefebvre, M.; Espinosa, G.; Gomez, Y.P.S. JRC Scientifics and Policy Reports-The Influence of the Common Agricultural Policy on Agricultural Landscape EUR 25459 EN:75; Publications Office of the European Union: Brusels, Belgium, 2012. [CrossRef]

3. Lima, M.L.; Romanelli, A.; Massone, H.E. Assessing groundwater pollution hazard changes under different socio-economic and environmental scenarios in an agricultural watershed. Sci. Total Environ. 2015, 530, 333-346. [CrossRef]

4. Rammel, C.; Stagl, S.; Wilfing, H. Managing complex adaptive systems - A co-evolutionary perspective on natural resource management. Ecol. Econ. 2007, 63, 9-21. [CrossRef]

5. Paolini, V.; Petracchini, F.; Segreto, M.; Tomassetti, L.; Naja, N.; Cecinato, A. Environmental impact of biogas: A short review of current knowledge. J. Environ. Sci. Health Part A 2018, 53, 899-906. [CrossRef] [PubMed]

6. Kelly, C.; Ferrara, A.; Wilson, G.A.; Ripullone, F.; Nolè, A.; Harmer, N.; Salvati, L. Community resilience and land degradation in forest and shrubland socio-ecological systems: Evidence from Gorgoglione, Basilicata, Italy. Land Use Policy 2015, 46, 11-20. [CrossRef] 
7. Biggs, E.M.; Bruce, E.; Boruff, B.; Duncan, J.M.; Horsley, J.; Pauli, N.; McNeill, K.; Neef, A.; van Ogtrop, F.; Curnow, J.; et al. Sustainable development and the water-energy-food nexus: A perspective on livelihoods. Environ. Sci. Policy $2015,54,389-397$. [CrossRef]

8. Young, O.R.; Berkhout, F.; Gallopin, G.C.; Janssen, M.A.; Ostrom, E.; van der Leeuw, S. The globalization of socio-ecological systems: An agenda for scientific research. Glob. Environ. Chang. 2006, 16, 304-316. [CrossRef]

9. Torres-Lima, P.; Pinel, S.L.; Conway-Gómez, K. Adaptive Governance for Resilience of Peri-Urban Socioecological Systems. In Resilient Cities; Springer International Publishing: Cham, Switzerland, 2019; pp. 43-58.

10. Racoviceanu, A.I.; Karney, B.W.; Kennedy, C.A.; Colombo, A.F. Life-Cycle Energy Use and Greenhouse Gas Emissions Inventory for Water Treatment Systems. J. Infrastruct. Syst. 2007, 13, 261-270. [CrossRef]

11. Steinhäußer, R.; Siebert, R.; Steinführer, A.; Hellmich, M. National and regional land-use conflicts in Germany from the perspective of stakeholders. Land Use Policy 2015, 49, 183-194. [CrossRef]

12. Scarlat, N.; Fahl, F.; Dallemand, J.-F. Status and Opportunities for Energy Recovery from Municipal Solid Waste in Europe. Waste Biomass Valorization 2019, 10, 2425-2444. [CrossRef]

13. Escalante, H.; Castro, L.; Gauthier-Maradei, P.; de la Vega, R.R. Spatial decision support system to evaluate crop residue energy potential by anaerobic digestion. Bioresour. Technol. 2016, 219, 80-90. [CrossRef]

14. Zareei, S. Evaluation of biogas potential from livestock manures and rural wastes using GIS in Iran. Renew. Energy 2018, 118, 351-356. [CrossRef]

15. Castellet-Viciano, L.; Torregrossa, D.; Hernández-Sancho, F. The relevance of the design characteristics to the optimal operation of wastewater treatment plants: Energy cost assessment. J. Environ. Manag. 2018, 222, 275-283. [CrossRef] [PubMed]

16. Cook, S.M.; Skerlos, S.J.; Raskin, L.; Love, N.G. A stability assessment tool for anaerobic codigestion. Water Res. 2017, 112, 19-28. [CrossRef]

17. Bardi, L.; Malusà, E.; Zoppellari, F.; Bosco, F.; Bergesio, B.; Bertin, L. Production of renewable energies and biomolecules from livestock and agro-industrial waste: The BIOMOLENER Project. J. Biotechnol. 2010, 150, 172. [CrossRef]

18. Sheets, J.P.; Yang, L.; Ge, X.; Wang, Z.; Li, Y. Beyond land application: Emerging technologies for the treatment and reuse of anaerobically digested agricultural and food waste. Waste Manag. 2015, 44, 94-115. [CrossRef] [PubMed]

19. Fodor, Z.; Klemeš, J.J. Waste as alternative fuel-Minimising emissions and effluents by advanced design. Process. Saf. Environ. Prot. 2012, 90, 263-284. [CrossRef]

20. Kousksou, T.; Allouhi, A.; Belattar, M.; Jamil, A.; el Rhafiki, T.; Arid, A.; Zeraouli, Y. Renewable energy potential and national policy directions for sustainable development in Morocco. Renew. Sustain. Energy Rev. 2015, 47, 46-57. [CrossRef]

21. Mastrangelo, M.E.; Weyland, F.; Herrera, L.P.; Villarino, S.H.; Barral, M.P.; Auer, A.D. Ecosystem services research in contrasting socio-ecological contexts of Argentina: Critical assessment and future directions. Ecosyst. Serv. 2015, 16, 63-73. [CrossRef]

22. Ma, J.; Scott, N.R.; Degloria, S.D.; Lembo, A.J. Siting analysis of farm-based centralized anaerobic digester systems for distributed generation using GIS. Biomass Bioenergy 2005, 28, 591-600. [CrossRef]

23. Farahani, R.Z.; Steadieseifi, M.; Asgari, N. Multiple criteria facility location problems: A survey. Appl. Math. Model. 2010, 34, 1689-1709. [CrossRef]

24. Höhn, J.; Lehtonen, E.; Rasi, S.; Rintala, J. A Geographical Information System (GIS) based methodology for determination of potential biomasses and sites for biogas plants in southern Finland. Appl. Energy 2014, 113, 1-10. [CrossRef]

25. Alonso, J.; Castro, P.; Martins, I.; Honrado, J.; Calafate, M.; Gonçalves, J.; Pratola, C. Framework for user-oriented quality evaluation routines (D5.3). In Ecopotential: Improving Future Ecosystem Benefits Through Earth Observations; European Union: Brusels, Belgium, 2017; pp. 1-156. Available online: https:/ / ec.europa.eu/research/participants/documents/downloadPublic? documentIds=080166e5b723633b\&appId=PPGMS (accessed on 1 September 2019).

26. Goodchild, M.F.; Li, L. Assuring the quality of volunteered geographic information. Spat. Stat. 2012, 1, 110-120. [CrossRef]

27. Theuerl, S.; Herrmann, C.; Heiermann, M.; Grundmann, P.; Landwehr, N.; Kreidenweis, U.; Prochnow, A. The Future Agricultural Biogas Plant in Germany: A Vision. Energies 2019, 12, 396. [CrossRef]

28. Fagbohun, B.; Aladejana, O. Integrating knowledge-based multi-criteria evaluation techniques with GIS for landfill site selection: A case study using AHP. Mater. Geoenviron. 2016, 63, 169-182. [CrossRef]

29. Coura, R.D. Biomethanization of Nitrogen Rich Agricultural and Urban Wastewaters: Biological Kinetics and Management Optimization Using Sequencing Batch Reactors. Ph.D. Thesis, ISA-University of Lisbon, Lisbon, Portugal, 2019.

30. Spigolon, L.M.; Giannotti, M.; la Rocca, A.P.; Russo, M.A.; Souza, N.D.C. Landfill siting based on optimisation, multiple decision analysis, and geographic information system analyses. Waste Manag. Res. 2018, 36, 606-615. [CrossRef]

31. Boroushaki, S.; Malczewski, J. Measuring consensus for collaborative decision-making: A GIS-based approach. Comput. Environ. Urban Syst. 2010, 34, 322-332. [CrossRef]

32. Malczewski, J. A Geographic Information Sciences Approach. In Spatial Multicriteria Decision Making and Analysis; Thill, J.E., Ed.; Routledge: Abingdon, UK, 2019; p. 393. [CrossRef]

33. Malczewski, J. GIS and Multi-Criteria Decision Analysis; Wiley: New York, NY, USA, 1999; p. 408.

34. Church, R.L. Geographical information systems and location science. Comput. Oper. Res. 2002, 29, 541-562. [CrossRef]

35. Malczewski, J. GIS-based multicriteria decision analysis: A survey of the literature. Int. J. Geogr. Inf. Sci. 2006, 20, 703-726. [CrossRef] 
36. Alonso, J.; Curado, M.; Silva, A.; Eça, P. Plano de ordenamento da Bacia Leiteira Primária do Entre Douro e Minho. Direção Reg. Agric. Entre Douro Minhon 2012, 1, 1-153.

37. Silva, S. Sistema de Apoio à Decisão Espacial Multicritério na Localização de Centrais de Biogás. Ph.D. Thesis, Universidade de Coimbra, Coimbra, Portugal, 2014. (In Portuguese)

38. Zubaryeva, A.; Zaccarelli, N.; del Giudice, C.; Zurlini, G. Spatially explicit assessment of local biomass availability for distributed biogas production via anaerobic co-digestion-Mediterranean case study. Renew. Energy 2012, 39, 261-270. [CrossRef]

39. Perpiña, C.; Martínez-Llario, J.C.; Pérez-Navarro, Á. Multicriteria assessment in GIS environments for siting biomass plants. Land Use Policy 2013, 31, 326-335. [CrossRef]

40. Thompson, E.; Wang, Q.; Li, M. Anaerobic digester systems (ADS) for multiple dairy farms: A GIS analysis for optimal site selection. Energy Policy 2013, 61, 114-124. [CrossRef]

41. Bojesen, M.; Birkin, M.; Clarke, G. Spatial competition for biogas production using insights from retail location models. Energy 2014, 68, 617-628. [CrossRef]

42. INE. Censos 2011; Instituto Naciona de Estatistica: Lisbon, Portugal, 2011.

43. Germany ATV-DYWK GFA. Rules and Standards; Dimensioning of Single Stage Actived Studge Plants; GFA Publishing company: Hennef, Germany, 2000.

44. CBPA. Código de Boas Praticas Agrícolas: Para a Proteção da Agua Contra a Poluição com Nitratos de Origem Agrícola; Ministério da Agricultura do Desenvolvimento Rural e das Pescas: Lisbon, Portugal, 1997.

45. Brito, L.; Alonso, J.; Rey-Grana, J. Gestão de efluentes nas explorações leiteiras do Entre Douro e Minho. Rev. Ciências Agrar. 2011, 36, 80-93.

46. Batzias, F.; Sidiras, D.; Spyrou, E. Evaluating livestock manures for biogas production: A GIS based method. Renew. Energy 2005, 30, 1161-1176. [CrossRef]

47. Braun, R. Anaerobic digestion: A multi-faceted process for energy, environmental management and rural development. In Improvement of Crop Plants for Industrial End Uses; Springer International Publishing: Cham, Switzerland, 2007; pp. 335-416.

48. AQPER. Association Quebecoise de la Production D'Energie Renouvelable. Available online: https://www.aqper.com/en/biogas (accessed on 27 July 2019).

49. Rohstoffe, V. Biogas Basisdaten Deutschland-Stand: Oktober 2008. 7p. Very Short But Comprehensive Overview of the Biogas Situation in Germany; Biogas Zorg: Munich, Germany, 2019; Available online: http:/ /www.fnr.de/fileadmin/allgemein/pdf/broschueren/ Broschuere_Basisdaten_Bioenergie_2018_web.pdf (accessed on 12 August 2019).

50. Santos, S. Viabilidad de las explotaciones lecheras es un escenario de desconexión del apoyo y condicionalidade: Un estudio de caso en el noroeste de Portugal. Ph.D. Thesis, Universidade Politecnica de Madrid, Madrid Spain, 2011.

51. Massé, D.; Lu, D.; Masse, L.; Droste, R. Effect of antibiotics on psychrophilic anaerobic digestion of swine manure slurry in sequencing batch reactors. Bioresour. Technol. 2000, 75, 205-211. [CrossRef]

52. Kitazono, Y.; Ihara, I.; Toyoda, K.; Umetsu, K. Degradation of veterinary antibiotics during anaerobic digestion of dairy manure. Water Pract. Technol. 2015, 10, 532-537. [CrossRef]

53. Van Epps, A.; Blaney, L. Antibiotic Residues in Animal Waste: Occurrence and Degradation in Conventional Agricultural Waste Management Practices. Curr. Pollut. Rep. 2016, 2, 135-155. [CrossRef]

54. Font-Palma, C. Methods for the Treatment of Cattle Manure-A Review. J. Carbon Res. 2019, 5, 27. [CrossRef]

55. Panichelli, L.; Gnansounou, E. GIS-based approach for defining bioenergy facilities location: A case study in Northern Spain based on marginal delivery costs and resources competition between facilities. Biomass Bioenergy 2008, 32, 289-300. [CrossRef]

56. Tuzkaya, G.; Önüt, S.; Tuzkaya, U.R.; Gülsün, B. An analytic network process approach for locating undesirable facilities: An example from Istanbul, Turkey. J. Environ. Manag. 2008, 88, 970-983. [CrossRef]

57. Tavares, G.; Zsigraiová, Z.; Semiao, V. Multi-criteria GIS-based siting of an incineration plant for municipal solid waste. Waste Manag. 2011, 31, 1960-1972. [CrossRef]

58. Ferretti, V.; Pomarico, S. Integrated sustainability assessments: A spatial multicriteria evaluation for siting a waste incinerator plant in the Province of Torino (Italy). Environ. Dev. Sustain. 2012, 14, 843-867. [CrossRef]

59. Sultana, A.; Kumar, A. Optimal siting and size of bioenergy facilities using geographic information system. Appl. Energy 2012, 94, 192-201. [CrossRef]

60. Sanchezlozano, J.M.; Teruel-Solano, J.; Soto-Elvira, P.L.; García-Cascales, M.S. Geographical Information Systems (GIS) and Multi-Criteria Decision Making (MCDM) methods for the evaluation of solar farms locations: Case study in south-eastern Spain. Renew. Sustain. Energy Rev. 2013, 24, 544-556. [CrossRef]

61. Chau, K.W.; Chan, I.Y.S.; Lu, W.; Webster, C. (Eds.) Proceedings of the 21st International Symposium on Advancement of Construction Management and Real Estate; Springer International Publishing: Cham, Switzerland, 2018.

62. Franco, C.; Bojesen, M.; Hougaard, J.L.; Nielsen, K. A fuzzy approach to a multiple criteria and Geographical Information System for decision support on suitable locations for biogas plants. Appl. Energy 2015, 140, 304-315. [CrossRef]

63. Villamar, C.A.; Rivera, D.; Aguayo, M. Anaerobic co-digestion plants for the revaluation of agricultural waste: Sustainable location sites from a GIS analysis. Waste Manag. Res. 2016, 34, 316-326. [CrossRef]

64. Lindkvist, E.; Johansson, M.T.; Rosenqvist, J. Methodology for Analysing Energy Demand in Biogas Production Plants-A Comparative Study of Two Biogas Plants. Energies 2017, 10, 1822. [CrossRef] 
65. Timonen, K.; Sinkko, T.; Luostarinen, S.; Tampio, E.; Joensuu, K. LCA of anaerobic digestion: Emission allocation for energy and digestate. J. Clean. Prod. 2019, 235, 1567-1579. [CrossRef]

66. Espinosa, M.P.; Pizarro-Irizar, C. Is renewable energy a cost-effective mitigation resource? An application to the Spanish electricity market. Renew. Sustain. Energy Rev. 2018, 94, 902-914. [CrossRef]

67. Saaty, T. Método de Análise Hierárquica; McGraw-Hill Makron Books: São Paulo, Brasil, 1991; p. 367.

68. ESRI. The Language of Spatial Analysis; ESRI: Redlands, CA, USA, 2011; pp. 189-197.

69. Church, R.; Medrano, A. University of California at Santa Barbara Location-allocation Modeling. Geogr. Inf. Sci. Technol. Body Knowl. 2018, 2018. [CrossRef]

70. ESRI. Location-Allocation Analysis layer: What Is a Location Allocation? 2019. Available online: https://desktop.arcgis.com/en/ arcmap/latest/extensions/network-analyst/location-allocation.htm (accessed on 24 August 2019).

71. Lomba, A.; Vicente, J.; Moreira, F.; Honrado, J. Effects of multiple factors on plant diversity of forest fragments in intensive farmland of Northern Portugal. For. Ecol. Manag. 2011, 262, 2219-2228. [CrossRef]

72. Cerqueira, J. Avaliação de bem-estar animal em bovinos de leite na região Norte de Portugal. Ph.D. Thesis, Instituto de Ciências Biomédicas Abel Salazar da Universidade do Porto, Porto, Portugal, 2012.

73. Thiriet, P.; Bioteau, T.; Tremier, A. Optimization method to construct micro-anaerobic digesters networks for decentralized biowaste treatment in urban and peri-urban areas. J. Clean. Prod. 2020, 243, 118478. [CrossRef]

74. Wang, J. Decentralized Biogas Technology of Anaerobic Digestion and Farm Ecosystem: Opportunities and Challenges. Front. Energy Res. 2014, 2. [CrossRef]

75. Comber, A.; Dickie, J.; Jarvis, C.; Phillips, M.; Tansey, K. Locating bioenergy facilities using a modified GIS-based locationallocation-algorithm: Considering the spatial distribution of resource supply. Appl. Energy 2015, 154, 309-316. [CrossRef]

76. Rajabifard, A. Spatial Enablement from an International Context-A Vision for the North and West Melbourne Corridor. In Spatial Data Access and Integration to Support Liveability: A Case Study in North and West Melbourne, 1st ed.; Rajabifard, A., Eagleson, S., Eds.; Centre for Spatial Data Infrastructures and Land Administration, University of Melbourne: Victoria, Australia, 2013; pp. 1-10. ISBN 978-0-9922918-0-8. 